UDC 519.248.6

DOI https://doi.org/10.32838/2710-4656/2021.6-2/08

Mehdiyeva G. I.

Military Academy named after Heydar Aliyev

\title{
THE PROBLEM OF COINCIDENCE IN TEXTS
}

There is a special lexicon of different fields of science. However, most of the scientific works published by the society are written in the language used by the people, and when reading each scientific and popular work, it is clear that it differs from the works of art. This difference is first of all reflected in the lexical structure and terms of these works. Thus, it is impossible to imagine scientific works without terms. The development of science and technology, the observation and study of the military state of have led to the emergence of new terms. Terms have a special place in the vocabulary of the language. Speaking about the position of terms in the language system, it was noted that the study of the history of terminology is not only a national-historical problem, but also an international problem of world science, human civilization, cultural relations and history of the peoples of the world. Looking at the history of the development of terminology, it is clear that in the last decade, a lot of research has been conducted on the theoretical and practical issues of terminology and the special function of terms, and many research papers on its origin and development. The language of military texts, or terminology used in military texts, is considered to be the oldest language form of the text. The process of internationalization of languages saves peoples from national isolation by creating conditions for their integration into international civilization and world cultural, ie scientific development. It also promotes the international education of members of society, ie language speakers, their integration into international development, the enrichment of the laws of internal development of languages, and expands the opportunities for expression.

Key words: military, international, term, borrowing, word, meaning.

Introduction. Documents of international treaties play an important role in the approach to international relations or rules, in their correct definition, and in the determination of their directions. The importance of such documents is highly developed in the context of modern international law. The quality of enforcement of international law is often questioned by the growing contract signing process. In addition, the universality of human rights through international treaties can be seen as an achievement. According to the international law, no interference in a sovereign state is allowed. In this sense, international treaty law can also be referred to as the 'meeting point of the need to assume international obligations'.

International agreements can also be named as conventions, protocols, acts, memorandums of understanding, regulations, etc. Of course, the terminology may change depending on the situation, but the basic meaning of an international agreement is contained in all terms. Each of them means 'combining the wills of two or more international entities in order to regulate their interests in accordance with international rules'. This definition reflects the importance of an international agreement. Thus, "international law" is determined in accordance with the interests of each foreign state. In modern international law, the importance of an "international agreement" for the establishment of international rules is very much felt. It is necessary to state that their importance is very important in the following spectrum:

1) The establishment of international institutions or mechanisms is used to be created to enforce international law. It should be noted that one of the classical and weak theories of international law is its ability to "force". It is said that international law has not been able to exert any effect on the absence of an 'enforcement' mechanism. Nevertheless, the controversy was largely set aside by the growing importance of the international treaty process. The Statute of Rome and similar documents of several provisional or transitional courts provided 'firmly established institutions or mechanisms' for the application of these rules to international law.

2) Expanding and organizing the 'universality' of human rights is one of the most important achievements of international treaties since 1945. Prior to World War II, the Geneva Conventions played a key role in drafting humanitarian laws to limit war and in promoting international human rights. Along with the ability to enforce human rights conventions, it has gained wider accusations. One of the most important features of these contracts is the 'contract mechanism' to fulfill the contractual obligation. 
Despite the fact that the agreements impose obligations on various organizations, the opportunities they create for states and people are enormous. The implementation of international agreements is supported by 'legal and moral sanctions'. The classic notion that a treaty binds only the parties is not entirely true in modern international law. The changing perspective of the international order after 1945 and the growing interdependence of states have created a positive atmosphere for states to 'take on their obligations under treaties', even though they are not parties.

This concept was reflected in the work "Certain German Interests in Polish Upper Silesia (Merits)" in 1926, entitled "Certain German Interests in Polish Upper Silesia". According to the Permanent Court of International Justice, for third countries, treaties are devoid of any legal effect: they are something done by others. In other words, treaties cannot impose obligations on third states or create legal rights. The classical view is still valid in principle. Of course, no state or entity is obligated to 'perform a non-party contractual obligation'. However, the traditional notion that an 'unaccepted or unsigned treaty' is/res inter alios acta/'is no longer valid, as no state close to modern affairs can dare to oppose the' spirit 'of the treaty.

Many countries are still unable to fully comply with the International Covenant on Civil and Political Rights. However, they can hardly set aside the values and principles set out in this act.

The article on the Vienna Convention on the Law of Treaties emphasizes the importance of such international agreements. These agreements show that third countries cannot do anything outside the agreement.

Discussion. It is known that the texts are identical in terms of their communicative-pragmatic styles. In all types of text, for example, international, literary, political, etc. pragmatic-communicative functions appear to be observed. In most of the texts, the conversation comes to the fore. Two main factors are identified in terms of the study of information transmitted within international texts: a) the interrelationship of the components of a communicative act within a military document and treaty; b) detection and study of the interaction of the components of the text formed within the communicative act in military documents and agreements.

As our research object is military documents and agreements, we focus on the study of linguistic criteria in the communication conditions observed in them. In international texts, the influence of nontextual factors on text comprehension is currently attracting the attention of researchers. In this case, the reader who is acquainted with military documents and agreements is conveyed visually or through reading the mechanism of action of those military documents and agreements, the composition of the components of the pragmatic aspect, the features of their realization for pragmatic purposes.

Analyses. The term 'pragmatics' is from Greek origin. It literally means "action or influence". Thus, we can say that pragmatics "learns the relationship between the subject who masters and studies any sign system and that system". As for the study of the international text in a pragmatic way, we can say that the influence of all the elements that make up military documents and agreements, the language in the text, the forms of speech, etc., is understood by the listener or reader. The transmission of international information means that that information affects the addressee. The influence of the speaker and the purpose of communication are combined, and as a result of them, the aspect of the international language realizes its communicative function. The transmission of information in international texts is an important factor. Both written and oral discourse play an important role in the transmission of information. In particular, the transmission of information plays a key role in any oral discourse. The study of the transmission of information in texts was still proposed by scholars of the Prague School of Linguistics [1, p. 153].

Later, in 1967, the issue of information transfer within the text was touched upon in the articles of M.A.K. Halliday. M.A.K. Halliday was interested in studying the transmission of information within the discourse and the structure of information in general, the study of ways of its transmission.

M.A.K. Halliday points out the role of intonation that is observed in the transmission of discourse information in English. Understands the intention and purpose of the sender of the information through the intonation that transmits or receives the information. This is also the case with military documents and agreements. After research, M.A.K. Halliday came to the conclusion that one of the main functions of intonation in military documents and contracts in English is to determine what kind of information the speaker conveys [9, p. 177]. In general, M.A.K. Halliday, who studied the transmission of information in the discourse, later tried to identify ways of organizing information in spoken language [9, p. 178]. He associated this connection with phonological understanding. The intonation, as mentioned above, is central to 
this relationship. While studying the connection, the syntactic ways of the structure of information began to be explored. According to M.A.K. Halliday, the speaker combines his speech into information units. The speaker is free to give information on how to start and how to end it. Research suggests that each language developer develops a specific articulatory program and uses certain acoustic features to accomplish his or her communicative intentions.

M.A.K. Hallidey proposes to emphasize the unit of intonation in the rhythmic structure of discourse. Each intonation unit usually contains an element of new information and indicates the interaction of the mix of old/new information with the prosodic (accented/unaccented) and lexical (pronoun/noun) realization of referents in international discourse. He writes: "The type of information is the choice made by the speaker, and the choice of information does not depend on the environment of military documents and agreements or the situation; it is the speaker's choice to give new information and to be reminded of information already given in international discourse" [9, p. 199-244].

Thus, it turns out that military documents and agreements are realized both depending on the intention of the transmitter and the form of influence of the negotiations. In the international text, content-meaning-international sign (sign means the lines, curves, diagrams, etc. that we usually come across in military documents and agreements) is a combination of language and writing forms, and in communication the factors interact. It should be noted that along with the realization of the pragmatic aspect in communication, a hierarchical factor is also observed. Hierarchical terms are a more important factor in military documents and agreements. Thus, a rapporteur or writer who transmits international information, etc. tries to establish a communication that attracts the attention of the reader or listener, in short, the recipient, it is more important to get a convincing relationship of the participants, as well as the implementation of their mutual understanding processes.

In international texts, in the communicativepragmatic situation, what information, where, to whom, what, etc. Different types of communication information are used in the realization of communicative situations such as in this case, the linguopragmatic aspect of the study of military documents and agreements requires a statement and interpretation of documents and agreements with full military content. The main issue is the purpose of military documents and agreements, the importance of the information conveyed in the text, the degree of persuasiveness, i.e. the interactivity between the subject of military documents and agreements and its addressee, the place, time, conditions and so on. Factors such as play an important role. The presence of verbal and non-verbal features in the communicative-pragmatic situation in the international text allows to reveal the pragmatic content of actualized language units. Often, in pragmatic documents and agreements, pragmatic transmitters are located outside the boundaries of language units, which requires the actualization of extralinguistic factors [3, p. 7].

The most important factor that reveals the pragmatism of the international text is the monologue-dialogue. Why monologue? Convincing the recipient is an important condition in international texts. In particular, persuasion becomes more consistent through monologue. For example, Hillary Clinton, who was trying to strengthen her platform in the presidential election in a purposeful way and on full international power, uses her monologue only through international discourse and can almost convince her listeners [5, p. 95].

Words derived from other languages create certain changes in the meaning of the derived word. Thus, if a word is taken from another language, then there is a big change in its semantic meaning. Multiple words usually have one or two meanings. For example, the French word "timbre" (petite pièce de papier que l'on colle sur un envoipostal) has many meanings, but in English it means temb (character or quality as opposed to the sound and intensity of a musical sound or voice). is. Then / cargo /(goods carried on a ship, aircraft, or motor vehicle transportation of bulk cargo) and / cask / (a large container like a barrel, made of wood, metal or plastic and used for storing liquids, typically alcoholic drinks ) words have many meanings in Spanish. These meanings are: / the goods carried in a ship / (goods carried on a ship); / a barrel for holding liquids / (Middle English Dictionary).

In some cases, a specialization of meaning can be observed. For example, as in the word / hangar /. The word in French means a large building with an extensive floor area, typically for housing aircraft. at the same time / revive / (revive; resurrect; tear the shroud); review; expresses the meaning of opinion. In English, it is used to indicate any theatrical entertainment. During the course of historical development, the acquisition of words sometimes acquired new meanings that were not found in the previous semantic structure. For example, in modern English, the word / move / has taken on several new meanings: 'propose ',' change one's flat', 
'mix with people'., but none of these words refer to the French word movoir (film).

Let's look at another word: / scope / / the extent of the area or subject matter that something deals with or to which it is relevant (scope; scope) "area, field", "opportunity, freedom of action". As a rule, the development of new meanings of words occurs 50 to 100 years after the acquisition of the word. J. Algeo writes that the semantic structure of derivations can change in other ways $[15$, p. 264]. Some meanings may be more general, and some meanings may be more specific. For example, the word terrorist / a person who uses unlawful violence and intimidation, especially against civilians, in the pursuit of political aims / means (terrorist). The word means in French / to rule a government by force or to oppose a government /.

Or / umbrella / a device consisting of a circular canopy of cloth on a folding metal frame supported by a central rod, used as protection against rain or sometimes sun (umbrella). In both languages, the word refers to an instrument used to protect against rain. In general, in most cases, the main meaning of the word is preserved throughout history, but sometimes it can become a secondary meaning. For example, words from the Scandinavian language, such as wing, root, take, still retain their original meanings. Sometimes a change in meaning is thought to be the result of associating derived words with familiar words. Such changes are somewhat similar in sound, but sometimes there is no connection between them. This process is called "folk etymology". In this case, the word changes either completely or partially. For example, in French the word oab sur (absolute) means "flood; overflow" means. In English, the word / rounder / (round) is sometimes associated with the word round. / Folle / - etymologization is a slow process; people initially try to predict foreign borrowing, but gradually popular use involves a new pronunciation and spelling.

Another phenomenon that requires special attention is the formation of other derivatives from derived words [15, p. 380]. New derivatives are generally formed with the help of productive affixes of Anglo-Saxon origin. The role of derived words in the formation and development of the vocabulary of the English language is related to the history of the language. Historical terms are discussed in which words from Latin, Scandinavian dialects, Norman and Persian, French and many other languages, including Russian, are introduced into English. Lexicology, on the other hand, has its own responsibilities in this regard, mainly in terms of material and assimilation outcomes. Since it belongs to the English language, the main problems of etymology and derived words are comprehensively and consistently addressed by S.E. Linville, mainly in terms of words.

The international text is considered to be more appropriate than other styles due to its official, scientific, social, etc. capabilities and the power of the means of expression [6, p. 195]. Literary text is a combination of imagination, fantasy, author's creativity, etc. When based on, military documents and agreements are based solely on concrete facts. Every wrong word, figure, or fact can ruin such a relationship, cause international conflict, or even disaster. It is no exaggeration to say that misinformation in military documents and contracts can be catastrophic if less information is used. J. Chambers notes that military documents and agreements should be treated as a persuasive activity [6, p. 200].

As we have noted, the main feature of international discourse is to rely on facts and convince the reader or listener. It is on the basis of fact that the recipient believes, and as a result of believing, communication arises. In his Principles of Internationalism, N.B. Checheina defines the peculiarities of military documents and agreements as follows: 1) types of exchanges transmitted in the international context; 2) delivery of visual information in military documents and contracts; 3 ) the importance of using the taboo language in military documents and agreements; 4) monologue and dialogue in international discourse; 3) international living standards of the country; 4) difficulty in understanding military documents and contracts [7, p. 100].

As we have noted, unlike literary texts, the main purpose of military documents and agreements is to provide accurate information and to convince the listener or reader. Therefore, when concluding military documents and agreements, it is necessary to pay attention to its systemic and international structure. In this case, of course, diagrams, curves, lines and figures can be used in a limited way to enhance the efficiency of the transmitted data.

Research shows that there are two main categories of military documents and agreements. The first is communicativeness, as mentioned above. Communication is important for military documents and agreements. The realization of this category is based on the system, function and system-language categories. The second is the category of the system. That is, the organization of military documents and agreements should be based on the system. The system of international text means informativeness, 
cohesion, integration, actual membership. These categories also apply to other types of texts. M.Y. Dimarskiy suggest the use of conditional sentences in military documents and contracts. They define the features of accuracy-inaccuracy, specificity and non-specificity, general-specificity as functional categories in determining the forecast put forward in military documents and contracts [8, p. 210].

These qualities link the communicative activity of military documents and agreements with the language system. The above-mentioned authors claim that predicativeness, nominativeness, causality, conditionality, accuracy, illustrativeness, determinability in military documents and contracts are considered to be system-language categories of military documents and contracts [10, p. 130-160]. In international texts, categories function equally, not separately. Categories of international texts, of course, can vary depending on the structure of the text. D. Liepina connects the multiplicity of text categories with their hierarchical irregularity, obligatory and optional features. He shows that textual categories differ qualitatively from text features [11, p. 3-8].

It is impossible to set a strict limit here. It is also possible to observe the features of the international text and the identification of categories of military documents and agreements.

S.N. Ilchenko believes that as a result of violation of the principle of partial and complete relation of speech signs, focusing on extralinguistic factors, the categories of text increase with the transfer of speech signs to the text [10, p. 12].

A.F. Papina notes that text categories are a mutually important feature of the text. These features reflect a certain part of the general meaning of the text through various language, speech and text means $[13$, p. 33].

The study of the definition of the main categories of the text began to be studied in the 80 s of the twentieth century. N. Chicherina identified four categories of text. They are considered time, space, executor, and event $[7$, p. 7]. S.N. Ilchenko mentioned above, distinguishes three categories of the text: competence, membership and modality [10, p. 34]. M.Y. Dimarskiy argues that these three categories are important for military documents and agreements. These forms are closely related to visual information. Functional forms, on the other hand, arise when the reader is acquainted with the content of military documents and agreements and directs him to various places in military documents and agreements [8, p. 153-155].

A.F. Papina distinguishes 5 main categories of the text: 1) participants of the communicative act; 2) events, processes and facts; 3 ) time (international period, international psychological situation, accuracy); 4) location of spatial and international processes; 5) evaluation; assessment can be axiological qualitative and quantitative, as well as rational, utilitarian, normative, theological, international [13, p. 208].

Thus, the categories of the text are generally: 1) integration; 2) communication; 3) retrosection; 4) continuum; 5) prospectus; 6) depth; 7) presupposition; 8) pragmatics, etc. These categories also apply to military documents and contracts.

M.Y. Dimarskiy claims that the category of the text means "deictic mode of the text". He notes that certainty and uncertainty take the whole object of military documents and contracts in relation to chronotope semantic elements [8, p. 268].

Conclusion. When talking about the categories of international text, it is impossible not to mention the theme and rhyme. Thus, the theme and rema are considered subcategories that regulate the course within the text. These include cohesion, semantics, and paradigms. In international texts, the subject combines units of different levels. These forms within the international text express themselves in a different formal-categorical way. Price, quality, correct quantity, actualization, international modulus, degree of authenticity, metaspect observed in international texts are such formal-categorical methods. Military terminology is also updated and developed in connection with events in the military environment in the country or in the world. Most of the words that appear in the military field have the characteristics of hybridization, origin and acquisition from other words.

\section{References:}

1. Абдуллаев К. Теоретические проблемы синтаксиса азербайджанского языка. Баку : MTM Innovation, 2016. $360 \mathrm{c}$.

2. Абдуллаев А. Актуальные ссылки: текст и дискурс. Баку : Зардаби ЛТД, 2011. 272 с.

3. Baumann K.D. The interdisciplinary concept of translational intertextuality, illustrated on the basis of LSP text networks. SYNAPS : SYNAPS Press, 2013. P. 7-17.

4. Baker C., Prys Jones S. Encyclopedia of Bilingualism and Bilingual Education. Multilingual Matters, 1998. $784 \mathrm{p}$.

5. Byrne J. Technical Translation. Dordrecht : Springer, 2006. 295 p. 
6. Chambers J.Wh. The Oxford companion to American military history (2nd ed.). USA : Oxford University Press, 1999. $295 \mathrm{p}$.

7. Чечеина Н.Б. Медиатекст как средство формирования медиаграмотности у студентов языковых факультетов. Москва : Старая Пресса, 2008. 232 с.

8. Димарский М.Ю. Учебные текстовые задачи и художественный текст. Москва : Эдиториал, 2001. 260 с.

9. Halliday M.A.K., Hasan R. Cohesion in English. London : Longman, 1976. P. 392.

10. Ильченко С. Интервью в журналистике. Санкт-Петербург : СПВКВ, 2003. 50 с.

11. Liepina D. Transfer of US military procurement-related terminology into Latvian. Vārds un tā pētišanas aspekti. 2011. № 5 (2). P. 243-247.

12. Myers-Scotton C. Multiple Voices: An Introduction to Bilingualism. Blackwell, 2006. 472 p.

13. Папина А.Ф. Текст: его единицы и глобальные категории. Москва : Эдиториал, 2002. 368 с.

14. Виноградов В.В. Вопросы терминологии. Москва : Высшее образование, 1944. 150 c.

15. John Algeo. Where Do All the New Words Come from? American Speech. 1980. Vol. 55. № 4. P. 264-277 (14 pages).

\section{Мехтісва Г. І. ПРОБЛЕМА ЗБІГУ В ТЕКСТАХ}

С особлива лексика різних галузей науки. Проте більшість публікованих наукових праць написано повсякденною мовою, при читанні кожного наукового й популярного твору стає ясно, що він відрізняється від творів мистецтва. Ця відмінність передусім відбивається на лексичній структурі й термінології цих творів. Неможливо уявити наукові праці без термінів. Розвиток науки й техніки, спостереження та вивчення військової справи кожної країни призвели до появи нових термінів. Терміни займають особливе місие в словнику військової мови. Говорячи про становище термінів у мовній системі, варто наголосити, що вивчення історії термінології є не лише національноісторичною, а й міжнародною проблемою світової науки, людської иивілізачії, культурних відносин та історії народів світу. Дивлячись на історію розвитку термінології, можемо констатувати, що за останне десятиліття проведено безліч досліджень з теоретичних і практичних питань термінології та особливої функиї̈ термінів, а також безліч дослідницьких робіт із ї̈ походження та розвитку. Мова військових текстів або термінологія, щяо використовується у військових текстах, уважається найстарішою мовною формою тексту. Прочес інтернаціоналізації мов рятує народи від національної ізоляиії, створюючи умови для їх інтеграції в міжнародну циивілізацію та світовий культурний, зокрема науковий розвиток. Він також сприяє міжнародній освіті членів суспільства, тобто носіїв мови, їх інтеграчї̈ в міжнародний розвиток, збагаченню законів внутрімнього розвитку мов і розщирюе можливості для самовираження.

Ключові слова: воєнний термін, міжнародний термін, запозичення, слово, значення. 